\title{
TEKNIK KONVENSIONAL PENGGUNAAN TUMBUHAN OBAT DI KAWASAN ESTUARIA TAKISUNG
}

\author{
EMA LESTARI
}

Staff Pengajar Jurusan Teknologi Industri Pertanian, Politeknik Negeri Tanah Laut, Jl. A. Yani, km 06, Ds. Panggung, kec. Pelaihari, Kab. Tanah Laut, Kalimantan Selatan emalestari@politala.ac.id

\begin{abstract}
Abstrak
Tumbuhan obat adalah tumbuhan yang memiliki khasiat obat dan digunakan sebagai obat dalam penyembuhan maupun pencegahan penyakit. Di daerah Takisung terdapat kawasan estuaria.Dikawasan tersebut ditumbuhi pepohonan, tumbuhan herba dan semak yang berpotensi sebagai tanaman obat.Masyarakat daerah setempat menggunakan tumbuhan obat sebagai alternatif dalam pengobatan, karena banyak ditemukan tumbuhan obat di sekitar mereka.Penelitian ini bertujuan untukmendapatkan informasi tentang bagaimana teknik penggunaan tumbuhan obat dikawasan estuaria Takisung oleh masyarakat di daerah tersebut.Metode yang digunakan dalam penelitian ini adalah metode diskriptif, dengan terjun secara langsung ke lapangan pada kawasan kiri dan kanan bantaran estuaria Pantai Takisung Kecamatan Takisung Kabupaten Tanah Laut. Hasil penelitian menunjukkan bahwa tumbuhan berkhasiat obat yang ditemukan di kawasan estuaria Takisung yang diketahui dan digunakan oleh masyarakat setempat terdapat 15 jenis tumbuhan.Teknik konvensional penggunaan tumbuhan obat masyarakat di kawasan estuaria meliputi: ${ }^{1}$ bahan di cuci bersih kemudian di rebus bersamaan, setelah dingin air rebusan tersebut disaring kemudian diminum, ${ }^{2}$ bahan dicuci bersih terlebih dahulu kemudian ditumbuk, setelah itu dioleskan, ${ }^{3}$ bahan dipanggang diatas api kemudian diusapkan, ${ }^{4}$ bahan diparut kemudian diperas, air yang dihasilkan diminum, ${ }^{5}$ bahan direbus kemudian dicucikan, ${ }^{6}$ bahan direndam dalam air terus dan diminum, ${ }^{7}$ bahan direbus dan dimakan, ${ }^{8}$ bahan cairan yang pada bagian tumbuhan kemudian diteteskan, ${ }^{9}$ bahandirebus dan air rebusan diminum, ${ }^{10}$ bahan dilumatkan hingga halus dan di oleskan, ${ }^{11}$ bahan dibersihkan lalu ditumbuk sampai halus, lalu dicampurkan dengan bahan lain lalu dioleskan, ${ }^{12}$ bahan dikeringkan kemudian direbus, lalu air rebusannya diminum, ${ }^{13}$ bahan ditumbuk kemudian dicampurkan dengan bahan lain kemudian diusapkan, ${ }^{14}$ bahan diremas-remas dan di usapkan.
\end{abstract}

Kata Kunci: Tumbuhan Obat, Kawasan Estuaria, Teknik Konvensional

\section{PENDAHULUAN}

Tumbuhan obat adalah tumbuhan yang memiliki khasiat obat dan digunakan sebagai obat dalam penyembuhan maupun pencegahan penyakit. Pengertian berkhasiat obat adalah mengandung zat aktif yang berfungsi mengobati penyakit tertentu atau 
mengandung efek resultan/sinergi dari berbagai zat yang berfungsi mengobati (Winarto, 2007). Oleh sebab itu upaya-upaya pelestarian tentang tumbuhan berkhasiat obat perlu dilakukan agar pengobatan tradisional tersebut tidak musnah akibat kemajuan teknologi dengan menggunakan obat-obatan modern.

Penelitian terhadap tumbuhan obat yang digunakan masyarakat tradisional di Kalimantan Selatan pada beberapa tempat yang telah dilakukan, seperti penelitian Dharmono (2001) menemukan 85 species tumbuhan obat di hutan Loksado Kabupaten Hulu Sungai Selatan.Penelitian Arifin dkk. (2006) di Kecamatan Loksado Kabupaten Hulu Sungai Selatan didapatkan 26 species tumbuhan obat yang terdiri atas golongan rumput, perdu, liana, semak dan pohon. Hasil penelitian tersebut menunjukkan bahwa tiap daerah memiliki karakteristik tumbuhan yang digunakan oleh masyarakat setempat.

Kecamatan Takisung Kabupaten Tanah Laut merupakan salah satu dari 9 Kecamatan yang terdapat di Kabupeten Tanah Laut. Di Kecamatan ini terdapat banyak areal pertanian, padang rumput, semak belukar, kawasan mangrove dan Estuaria. Di setiap kawasan tersebut ditumbuhi banyak pepohonan, tumbuhan herba dan semak yang berpotensi sebagai tanaman obat. Penggunaan tumbuhan berkhasiat obat oleh masyarakat setempat disebabkan oleh beberapa hal, yaitu keengganan masyarakat mendatangi Pusat Kesehatan Masyarakat (PUSKESMAS).Selain itu yang menjadi penyebab mendasar masyarakat menggunakan tumbuhan obat sebagai alternatif dalam pengobatan karena banyak ditemukan tumbuhan obat di sekitar mereka.

Winarto (2007) menjelaskan bahwa pada umumnya bahan baku obat tradisional berupa bahan tanaman segar, dan penanganannya hanya dengan ditumbuk, diseduh, dibakar, atau direbus dan dalam penggunaan tanaman obat sebagai obat bisa dengan cara diminum, ditempel, dan dihirup. Sehingga penggunaannya dapat memenuhi konsep kerja reseptor sel dalam menerima senyawa kimia atau rangsangan.Hal tersebut tentu saja berbeda dengan obat-obatan medis yang telah dipatenkan. Obat-obatan itu membutuhkan peralatan canggih dalam proses pembuatannya dan membutuhkan waktu sekitar 25 tahun untuk menjadi sebuah obat yang diakui oleh Badan Kesehatan Dunia (WHO). Lamanya waktu pengakuan tersebut tak lain untuk melakukan beberapa kali uji klinis sampai obat tersebut mencapai khasiat yang optimum dan memiliki efek samping yang kecil. Tentu saja proses tersebut membutuhkan biaya yang sangat besar sehingga harganya menjadi mahal. Belum lagi ditambah dengan biaya produksi, biaya promosi, dan biaya pemasaran. 
Berdasarkan uraian diatas penelitian bertujuan untuk mendapatkan informasi tentang bagaimana teknik penggunaan tumbuhan obat dikawasan estuaria Takisung oleh masyarakat di daerah tersebut.

\section{TINJAUAN PUSTAKA}

Tumbuhan obat atau biofarmaka didefinisikan sebagai jenis tanaman yang sebagian, seluruh tanaman dan atau eksudat tanaman tersebut digunakan sebagai obat, bahan atau ramuan obat-obatan. Eksudat tanaman adalah isi sel yang secara spontan keluar dari tanaman atau dengan cara tertentu sengaja dikeluarkan dari selnya. Eksudat tanaman dapat berupa zat-zat atau bahan-bahan nabati lainnya yang dengan cara tertentu dipisahkan/diisolasi dari tanamannya (Herdiani, 2012).

Dalam penggunaan tumbuhan obat sebagai obat bisa dengan cara diminum, ditempel, untuk mencuci/ mandi, dihirup sehingga penggunaannya dapat memenuhi konsep kerja reseptor sel dalam menerima senyawa kimia atau rangsangan. Hingga sekarang, pengobatan tradisional masih diakui keberadaannya dikalangan masyarakat luas. Ini sejalan dengan kebijakan pemerintah yang terus membina dan mengembangkannya. Salah satu pengobatan tradisional yang sedang trend saat ini adalah ramuan tanaman obat secara empirik, ramuan tradisional dengan tanaman obat paling banyak digunakan oleh masyarakat. Penggunaan ramuan tradisonal tidak hanya untuk menyembuhkan suatu penyakit, tetapi juga untuk menjaga dan memulihkan kesehatan (Stepanus, 2011).

Menurut Mangan (2003) cara pengobatan yang ada di kalangan masyarakat sekarang bisa disimpulkan kepada dua tipe pengobatan yaitu pengobatan cara barat yang bersifat moderen serta pengobatan cara timur yang bersifat alternatif dan sering kali disebut pengobatan tradisional. Secara umum, pengobatan timur bertujuan untuk meningkatkan sistem imun, menghambat pertumbuhan penyakit, mengurangi keluhan pengguna dan memperbaiki fungsi badan tubuh. Berbeda dengan pengobatan barat di mana sebagai contohnya bisa membuang tumor atau kanker dengan pembedahan, membunuh sel kanker dengan kemoterapi ataupun melakukan radioterapi untuk membunuh sel kanker yang kebanyakannya bersifat invasif pada tubuh manusia. Paradigma yang diterapkan dalam pengobatan barat adalah 'illness is the enemy' dan pengobatan timur pula dengan paradigma 'illness is not an enemy but caused unbalancing energy' menyebabkan perbedaan cara pandang masyarakat serta cara aplikasi keduanya pada upaya pelayanan kesehatan pada masyarakat. Meskipun 
demikian pengobatan tradisional ini diharapkan berkembang bersama pengobatan moderen supaya bisa saling mendukung dalam memberikan pelayanan kesehatan yang optimal pada masyarakat (Mushito, 2002).

Penelitian-penelitian tentang tumbuhan obat dan penggunaannya yang pernah dilakukan di tempat dan waktu yang berbeda seperti penelitian yang dilakukan oleh Sada dan Tanjung (2010) di Kampung Nansfori Distrik Supiori Utara, Kabupaten Supiori-Papua meneliti Keragaman Tumbuhan Obat yang menunjukkan terdapat 48 jenis dan 32 famili yang dilakukan dengan cara yang masih sederhana yaitu secara langsung (tanpa diolah) maupun tidak langsung (direbus dan dirauh atau dipanaskan) dan tidak menggunakan takaran tertentu. Setyowati (2010) di Kalimantan Timur meneliti Etnofarmakologi dan Pemakaian Tanaman Obat Suku Dayak Tunjung yang menunjukkan 47 jenis tumbuhan yang berkhasiat sebagai obat tradisional diantaranya sebagai obat kulit, masalah kewanitaan, pencernaan, ispa, mulut, demam, duiretika, dll, yang cara pengolahannya dan penggunaannya masih secara sederhana.

Rahayu, dkk (2006) di Pulau Wawonii Sulawesi Tenggara meneliti tentang Pemanfaatan Tumbuhan Obat Secara Tradisional oleh Masyarakat Lokal yang menunjukkan di pulau Wawonii tercatat 73 jenis tumbuhan yang digunakan oleh masyarakat setempat sebagai bahan obat tradisional dan perawatan pasca persalinan. Dari ketiga penelitian tersebut dapat terlihat bahwa tumbuhan obat yang diteliti cara pengolahannya dan penggunaannya masih secara sederhana.

\section{METODE PENELITIAN}

Metode yang digunakan dalam penelitian ini adalah metode diskriptif. Pengambilan data dilakukan dengan terjun secara langsung ke lapangan pada kawasan kiri dan kanan bantaran Estuaria Pantai Takisung Kecamatan Takisung Kabupaten Tanah Laut. Teknik pengambilan sampel menggunakan teknik jelajah pada daerah bantaran atau tepian estuaria sampai dengan salinitas 17 ppm ke arah hulu sampai 1000 meter dengan lebar bantaran atau tepian estuaria 10 meter ke arah daratan di sepanjang estuaria.Pengambilan sampel tumbuhan obat dilakukan bersama-sama dengan masyarakat yang ahli memanfaatkan tumbuhan obat yang tumbuh di kawasan estuaria Takisung Kabupaten Tanah Laut. Data hasil penelitian dianalisissecara diskriptif dengan menggunakan pustaka. 


\section{HASIL DAN PEMBAHASAN}

\section{Hasil}

Tumbuhan berkhasiat obat yang ditemukan di kawasan estuaria Takisung yang diketahui dan digunakan oleh masyarakat setempat terdapat 15 tanaman seperti pada tabel berikut ini.

Tabel Tumbuhan obat yang ditemukan di kawasan Estuaria Takisung Kabupaten Tanah Laut yang digunakan oleh masyarakat setempat.

\begin{tabular}{|c|c|c|c|}
\hline No. & Nama tumbuhan & $\begin{array}{c}\text { Organ } \\
\text { yang } \\
\text { digunakan }\end{array}$ & Kegunaan \\
\hline 1. & $\begin{array}{l}\text { Alalang (Imperata cylindrica } \\
\text { L.) }\end{array}$ & Akar & $\begin{array}{l}\text { Peluruh air seni, hipertensi, } \\
\text { demam karena buang air kecil } \\
\text { berdarah, sakit pinggang. }\end{array}$ \\
\hline 2. & $\begin{array}{l}\text { Lambai-lambai (Lindernia } \\
\text { tripolia) }\end{array}$ & Daun & Sakit Kepala \\
\hline 3. & Mengkudu (Morinda citrifolia) & $\begin{array}{l}\text { Akar, daun } \\
\text { dan buah }\end{array}$ & $\begin{array}{l}\text { Mengobati memar, sakit } \\
\text { pinggang, Luka bagian luar, } \\
\text { Menurunkan tekanan darah tinggi }\end{array}$ \\
\hline 4. & Piai (Acrosthicum aureum) & Daun & Hipertensi \\
\hline 5. & Bamban (Donax cannaeformis) & Daun & Obat tetes mata \\
\hline 6. & $\begin{array}{l}\text { Karamunting (Melastoma } \\
\text { candidum D. Don.) }\end{array}$ & $\begin{array}{l}\text { Akar dan } \\
\text { daun }\end{array}$ & keputihan, sariawan dan diare \\
\hline 7. & $\begin{array}{l}\text { Daun Rumput jepang } \\
\text { (Eupatorium odoratum) }\end{array}$ & Daun & Hipertensi \\
\hline 8. & Waru (Hibiscus tiliaceus) & Daun & Obat gatal-gatal \\
\hline 9. & Beluntas (Pluchea indica) & Daun & $\begin{array}{l}\text { menghilangkan bau badan dan } \\
\text { penambah nafsu makan }\end{array}$ \\
\hline 10. & $\begin{array}{l}\text { Pandan laut (Pandanus } \\
\text { tectorius) }\end{array}$ & Bunga & Obat jerawat \\
\hline 11. & $\begin{array}{l}\text { Kangkung laut(Ipomea pes } \\
\text { caprae Rotb) }\end{array}$ & $\begin{array}{l}\text { Daun dan } \\
\text { bunga }\end{array}$ & $\begin{array}{l}\text { Penyakit kulit dan obat untuk anti } \\
\text { nyamuk }\end{array}$ \\
\hline 12. & Jarak (Ricinus communis L.) & $\begin{array}{l}\text { Akar dan } \\
\text { daun }\end{array}$ & Memar dan luka \\
\hline 13. & $\begin{array}{l}\text { Lukut Simbar (Drynaria } \\
\text { sparsisora Moore, Linn) }\end{array}$ & Akar & $\begin{array}{l}\text { Obat sakit mata dan untuk obat } \\
\text { mencret }\end{array}$ \\
\hline 14. & Jayanti (Sesbania sesban Merr) & $\begin{array}{l}\text { Daun, akar } \\
\text { dan biji }\end{array}$ & Demam, TBC dan kencing nanah \\
\hline 15. & $\begin{array}{l}\text { Rambai bintang (Sonneratia } \\
\text { caseolaris) }\end{array}$ & $\begin{array}{l}\text { Buah dan } \\
\text { daun }\end{array}$ & $\begin{array}{l}\text { Buah bisa dimakan dan dapat } \\
\text { digunakan sebagai bahan ramuan } \\
\text { bedak dingin sedangkan daun } \\
\text { dapat mengobati cacar }\end{array}$ \\
\hline
\end{tabular}




\section{Pembahasan}

Berikut merupakan teknik penggunaan atau cara menggunakan tumbuhan obat di kawasan Estuaria Takisung oleh masyarakat setempat.

1. Alalang (Imperata cylindrica $\mathrm{L}$. )

Alalang bermanfaat untuk mengobati batuk darah, hipertensi, peluruh air seni dan sakit pinggang. Bagian yang digunakan adalah akarnya.Hal ini terdapat dalam Hariana (2004), yang menyatakan bahwa bagian yang digunakan pada tumbuhan alalangadalah akarnya (rimpang) yang digunakan untuk pengobatan peluruh air seni, kencing berdarah, radang ginjal akut dan sakit kuning (hepatitis).

2. Lambai-lambai (Lindernia Tripolia)

Lambai-lambai bermanfaat untuk mengobati sakit kepala dan demam, yang biasa digunakan adalah bagian daunnya. Cara pembuatannya adalah daunnya dicuci bersih terlebih dahulu kemudian ditumbuk, setelah itu dioleskan kekepala (dahi).

\section{Mengkudu (Morinda citrifolia)}

Mengkudu yang dapat digunakan sebagai obat adalah daun dan akar. Daun berfungsi untuk mengobati luka bagian luar, akar berfungsi untuk menobati memar dan sakit pinggang, buahnya berfungsi untuk menurunkan tekanan darah tinggi. Cara menggunakannya untuk mengobati luka, daun mengkudu dipanggang diatas api kemudian diusapkan kebagian yang luka. Untuk menurunkan darah tinggi, buah mengkudu diparut kemudian diperas, air yang dihasilkan ditambahi garam lalu diminum. Untuk memar, akarnya direbus kemudian ketika masih hangat dicucikan kebagian yang memar. Untuk sakit pingang akar mengkudu direndam dalam air terus diminum. Menurut Winarto (2007) hampir semua bagian dari tumbuhan mengkudu dapat digunakan sebagai obat, yaitu akar, daun, buah, kulit batang, bunga dan biji.. Akar mengkudu dapat digunakan untuk mengobati luka bekas terpukul dan eksim. Kulit batang mengkudu bermanfaat untuk mengobati sakit perut, disentri, luka terpukul dan eksim. Daun mengkudu juga bermanfaat untuk mengobati kencing manis, dan biji mengkudu juga bermanfaat untuk obat kuat. Buah mengkudu dapat digunakan untuk mengobati penyakit radang usus, ludah berdarah, pelancar kencing, batuk, radang amandel, limfa bengkak, liver, sariawan, tekanan darah tinggi, cacar air, beri-beri dan sembelit.

\section{Paku piai (Acrosthicum aureum)}

Paku piai dapat digunakan sebagai penurun darah tinggi, yang dapat digunakan sebagai obat adalah daunnya. Cara penggunaannya yaitu dengan cara direbus, bisa 
dibuat lalap dicampur dengan sayur-sayur lain. Sastrapradja (1980) menyatakan bahwa, paku laut atau paku piai dapat digunakan sebagai obat luka dan bisul.

\section{Bamban (Donax cannaeformis)}

Bamban dapat digunakan sebagai obat mata. Cara penggunaannya yaitu dengan meneteskan air yang pada daun muda yang masih menggulung pada mata. Menurut Winarto (2007) daun bamban berkhasiat sebagai obat bisul, obat bengkak, obat sakit karena gigitan ular dan obat tetes mata.

\section{Karamunting (Melastoma candidum D. Don)}

Karamunting digunakan sebagai obat keputihan, sariawan dan diare. Bagian yang digunakan adalah akar dan daun. Cara pembuatannya yaitu daun direbus hingga mendidih dalam 3 gelas air kemudian disaring, dan di dinginkan kemudian diminum, untuk penyakit keputihan. Untuk sariawan dan diare akar dan daunnya direbus hingga mendidih dalam 3 gelas air kemudian disaring, dan didinginkan kemudian diminum.Wijayakusuma (1992) dan Heyne (1987) menyatakan bahwa karamunting memiliki manfaat untuk mengobati gangguan pencernaan, hepatitis, keputihan, sariawan, mimisan, dan bisul. Bagian yang di pakai adalah akar, daun dan seluruh tanaman.

\section{Rumput jepang (Eupatorium odoratum)}

Rumput jepang digunakan sebagai obat darah tinggi atau hipertensi. Bagian yang digunakan adalah daun. Cara menggunakannya yaitu dengan merebus daun rumput jepang dan air rebusan diminum.

\section{Waru (Hibiscus tiliaceus)}

Waru bermanfaat untuk obat gatal-gatal yang di gunakan adalah bagian daunnya. Cara penggunaannya daun dilumatkan hingga halus dan di tambahkan kapur sirih kemudian di oleskan ke bagian yang gatal.Hal ini tidak sama dalam Plantamor (2011), menyatakan bahwa daun berkhasiat sebagai anti radang, antitoksik, peluruh dahak, dan peluruh kencing. Akar berkhasiat sebagai penurun panas dan peluruh haid. Bagian yang digunakan adalah daun, akar, dan bunga. Daun waru digunakan untuk pengobatan: TBC, batuk, sesak napas, radang amandel (tonsilitis), demam, berak darah dan lendir pada anak, muntah darah, radang usus, bisul, abses, keracunan singkong, penyubur rambut, rambut rontok. Akar digunakan untuk mengatasi terlambat haid, demam. Bunga digunakan untuk pengobatan radang mata. 


\section{Beluntas (Pluchea indica)}

Beluntas digunakan untuk menghilangkan bau badan dan penambah nafsu makan. Bagian yang digunakan adalah daunnya. Cara menggunakannya yaitu dengan merebus daun beluntas, atau diseduh sebagai teh, kemudian langsung diminum.Purnobasuki (2004), daun dan akar dari Pluchea indica berkhasiat sebagai obat penurun panas.Daun segarnya digunakan sebagai obat borok dan bisul. Rokok yang terbuat dari kulit batangnya dimanfaatkan sebagai pengurang sakit sinusitis, daun dan tunas muda yang ditumbuk dan dicampur alkohol digunakan sebagai obat rematik dan sakit kudis.

\section{Pandan Laut (Pandanus tectoris)}

Pandan laut berfungsi untuk obat jerawat. Bagian yang digunakan adalah bunganya. Cara penggunaannya adalah bunga dari pandan laut diambil lalu dibersihkan. Setelah itu lalu ditumbuk sampai halus, lalu dicampurkan kebedak dingin. Manfaat lebih jauh tentang tumbuhan pandan laut dapat diketahui dengan lengkap. Seperti yang dijelaskan oleh Wetlants (2008) yang menyatakan bahwa pandan ini bermanfaat untuk mengobati lemah saraf, rematik dan pegal linu, gelisah, rambut rontok, menghitamkan rambut dan menghilangkan ketombe.

\section{Kangkung laut (Ipomea pes caprae)}

Kangkung pantai berfungsi untuk obat sakit gigi. Bagian yang digunakan adalah akar. Cara penggunaannya adalah akar dikeringkan kemudian direbus, lalu air rebusannya diminum.Wijayakusuma (1992) menyatakan bahwa tumbuhan ini dapat digunakan untuk mengobati rematik, bisul dan koreng, wasir berdarah dan sakit gigi. Bagian tumbuhan yang dipakai yaitu seluruh tanaman.

\section{Jarak (Ricinus communis)}

Jarak yang dapat digunakan sebagai obat adalah akar dan daunnya. Bagian akar berfungsi untuk obat memar dan daunnya berfungsi untuk obat luka. Cara masyarakat desa takisung menggunakan tanaman jarak yaitu untuk obat luka pucuk daun ditumbuk kemudian dicampurkan dengan bedak dingin, setelah itu diusapkan pada bagian yang luka. Digunakan terus sampai luka mengering. Untuk obat memar, akar dibersihkan lalu direbus, kemudian air rebusan yang masih hangat digunakan untuk mencuci bagin yang memar. Wetlands (2008) menyatakan biji jarak terasa manis, pedas, netral dan digunakan untuk mengobati kanker mulut rahim dan kulit, kelumpuhan otot muka, TBC kelenjar, bisul, koreng dan infeksi jamur. 


\section{Lukut simbar (Drynaria sparsisora)}

Lukut simbar bermanfaat untuk obat sakit mata dan untuk obat mencret. Bagian yang digunakan adalah akar. Cara penggunaannya adalah mengambil cairan yang ada di akar. Sastrapradja (1980) menyatakan bahwa rimpangDrynaria sparsisora berkhasiat mengobati memar atau bengkak karena terlalu banyak berjalan. Selain itu juga berguna untuk menghilangkan bercak-bercak dimuka.

\section{Jayanti (Sesbania sesban Merr)}

Jayanti bermanfaat untuk obat demam, TBC dan kencing nanah.Bagian yang digunakan adalah daun, akar dan biji. Cara pembuatannya untuk obat demam adalah ambil daun secukupnya kemudian diremas-remas dan setelah itu di usapkan pada badan, untuk obat TBC yaitu dengan cara mengambil daun secukupnya kemudian ditumbuk dan di beri air dan disaring untuk kemudian diminum airnya, untuk obat kencing nanah cukup dengan mengambil bagian akar jayanti dicampur daun sirih dan direbus kemudian disaring dan diminum air hasil rebusan tersebut. Wijayakusuma (1993), yang menyatakan bahwa daun, akar, biji, kulit, dan minyak jayanti dapat bermanfaat menyembuhkan penyakit demam, cacingan, TBC (tuberculosa), radang selaput lendir air mata, infeksi ginjal, kencing kurang lancer, kencing nanah, demam, batuk, dan keguguran.

\section{Rambai bintang (Sonneratia caseolaris)}

Rambai bintang bermanfaat untuk obat mengobati cacar, buah bisa dimakan dan dapat digunakan sebagai bahan ramuan bedak dingin. Bagian yang digunakan adalah daun dan buah. Cara penggunaannya adalah daun ditumbuk halus kemudian campur dengan bedak dingin kemudian diusapkan pada bagian tubuh yang terkena cacar.

Berdasarkan uraian di atas dapat diketahui bahwa masyarakat di kawasan estuaria Takisung menggunakan tumbuhan obat untuk keperluan mereka dilakukan secara konvensional, yang meliputi :

1. Bahan di cuci bersih kemudian di rebus bersamaan, setelah dingin air rebusan tersebut disaring kemudian diminum.

2. Bahan dicuci bersih terlebih dahulu kemudian ditumbuk, setelah itu dioleskan.

3. Bahan dipanggang diatas api kemudian diusapkan.

4. Bahandiparut kemudian diperas, air yang dihasilkan diminum.

5. Bahandirebus kemudian dicucikan.

6. Bahandirendam dalam air terus dan diminum.

7. Bahandirebus dan dimakan. 
8. Bahan cairan yang pada baggian tumbuhan kemudian diteteskan.

9. Bahandirebus dan air rebusan diminum.

10. Bahandilumatkan hingga halus dan di oleskan.

11. Bahandibersihkan lalu ditumbuk sampai halus, lalu dicampurkan dengan bahan lain lalu dioleskan.

12. Bahandikeringkan kemudian direbus, lalu air rebusannya diminum.

13. Bahanditumbuk kemudian dicampurkan dengan bahan lainkemudian diusapkan.

14. Bahan diremas-remas dan di usapkan.

\section{KESIMPULAN}

1. Tumbuhan berkhasiat obat yang ditemukan di kawasan estuaria Takisung yang diketahui dan digunakan oleh masyarakat setempat terdapat 15 jenis tumbuhan.

2. Teknik konvensional penggunaan tumbuhan obat masyarakat di kawasan estuaria meliputi: bahan di cuci bersih kemudian di rebus bersamaan, setelah dingin air rebusan tersebut disaring kemudian diminum, bahan dicuci bersih terlebih dahulu kemudian ditumbuk, setelah itu dioleskan, bahan dipanggang diatas api kemudian diusapkan, bahan diparut kemudian diperas, air yang dihasilkan diminum, bahan direbus kemudian dicucikan, bahan direndam dalam air terus dan diminum, bahan direbus dan dimakan, bahan cairan yang pada baggian tumbuhan kemudian diteteskan, bahandirebus dan air rebusan diminum, bahan dilumatkan hingga halus dan di oleskan, bahan dibersihkan lalu ditumbuk sampai halus, lalu dicampurkan dengan bahan lain lalu dioleskan, bahan dikeringkan kemudian direbus, lalu air rebusannya diminum, bahan ditumbuk kemudian dicampurkan dengan bahan lain kemudian diusapkan, bahan diremas-remas dan di usapkan.

\section{DAFTAR PUSTAKA}

Dharmono, 2001.Inventarisasi Tumbuhan Obat Masyarakat Suku Dayak Bukit Di Hutan Loksado Kabupaten Hulu Sungai Selatan Kalimantan Selatan. Banjarmasin. Laporan Penelitian. Universitas Lambung Mangkurat. Banjarmasin (tidak Dipublikasikan).

Hariana, Arief. 2007. Tumbuhan obat dan khasiatnya. Penebar swadaya, Jakarta.

Herdiani, E. 2012. Potensi Tanaman Obat. http://www.bbpp-lembang.info.com

Heyne, K. 1982. Tumbuhan Berguna Indonesia II.Badan Penelitian dan Pengembangan Kehutanan. Departemen Kehutanan. Jakarta. 
Mangan, Y. 2003. Cara Menaklukan Kanker. Agromedia Pustaka. Jakarta.

Mursito, B. 2002. Ramuan Tradisional untuk Pengobatan Jantung. Penebar Swadaya. Jakarta.

Plantamor. 2011. http://www.plantamor.com

Purnobasuki, Hery.2004. Potensi Mangrove Sebagai Tanaman Obat.Universitas Airlangga, Surabaya.

Rahayu, M., Sunarti S., Diah Sulistiarini, Suhardjono Prawiroatmojo. 2006. Pemanfaatan Tumbuhan Obat secara Tradisional oleh Masyarakat Lokal di Pulau Wawonii Selawesi Tenggara. Jurnal Biodiversitas. 7(3) 245-250.

Sada, J. dan Tanjung Rosye H.R. 2010. Keragaman Tumbuhan Obat Tradisional di Kampung Nansfori Distrik Supiori Utara, Kabupaten Supiori-Papua. Jurnal Biologi Papua. 2(2) 39-46.

Sastrapradja, Mogea. 1980. Jenis Paku Indonesia. LBN-LIPI. Balai pustaka, Bogor.

Setyowati, Francisca Murti. 2010. Etnofarmakologi dan Pemakaian Tanaman Obat Suku Dayak Tanjung di Kalimantan Timur. Media Litbang Kesehatan. Vol XX, No 3.

Stepanus. 2011. Faktor-faktor yang Mempengaruhi Tanaman Pengembangan Tanaman Obat Keluarga di desa Pulau Sapi Kecamatan Mentarang Kabupaten Malinau. http://kumpulanbungamawarku.blogspot.com

Wetlands. 2008. Tumbuhan mangrove. http/www.wetlands.or.i/mangrove

Wijayakusuma, Hembing. 1992. Tanaman Berkhasiat Obat Di Indonesia.Jilid 1. Pustaka Kartini. Jakarta.

Winarto, W.P. 2007.Tanaman Obat Indonesia Untuk Pengobat Herbal. Karyasari Herba Media, Jakarta. 